\title{
Effectiveness of heat and moisture exchangers in preventing ventilator-associated pneumonia in critically ill patients: a meta-analysis
}

Mayra Gonçalves Menegueti ${ }^{1,2 *}$, Maria Auxiliadora-Martins ${ }^{2}$ and Altacílio Aparecido Nunes ${ }^{3}$

\begin{abstract}
Background: Patients may acquire ventilator-associated pneumonia (VAP) by aspirating the condensate that originates in the ventilator circuit upon use of a conventional humidifier. The bacteria that colonize the patients themselves can proliferate in the condensate and then return to the airways and lungs when the patient aspirates this contaminated material. Therefore, the use of HME might contribute to preventing pneumonia and lowering the VAP incidence. The aim of this study was to evaluate how the use of HME impacts the probability of VAP occurrence in critically ill patients.

Methods: On the basis of the acronym "PICO" (Patient, Intervention, Comparison, Outcome), the question that guided this review was "Do critically ill patients under invasive mechanical ventilation present lower VAP incidence when they use HME as compared with HH?". Two of the authors of this review searched the databases PUBMED/ Medline, The Cochrane Library, and Latin-American and Caribbean Literature in Health Sciences, LILACS independently; they used the following keywords: "heat and moisture exchanger", AND "heated humidifier", AND "ventilator-associated pneumonia prevention". This review included papers in the English language published from January 1990 to December 2012.

Results: This review included ten studies. Comparison between the use of HME and $\mathrm{HH}$ did not reveal any differences in terms of VAP occurrence $(\mathrm{OR}=0.998 ; 95 \% \mathrm{Cl}$ : $0.778-1.281)$. Together, the ten studies corresponded to a total sample of 1077 and 953 patients in the HME and HH groups, respectively; heterogeneity among the investigations was low $\left(I^{2}<50 \%\right)$. Information about the outcome mortality was available in only eight of the ten studies. The use of HME and $\mathrm{HH}$ did not afford different results in terms of mortality ( $\mathrm{OR}=1.09 ; 95 \% \mathrm{Cl}: 0.864-1.376)$. The total sample size was 884 and 762 patients, respectively. Heterogeneity among the studies was low $\left(I^{2}=0.0 \%\right)$.
\end{abstract}

Conclusion: Current meta-analysis was not sufficient to definitely exclude an associate between heat and moisture exchangers and VAP. Despite the methodological limitations found in selected clinical trials, the current meta-analysis suggests that HME does not decrease VAP incidence or mortality in critically ill patients.

Keywords: Ventilator-associated pneumonia, Heat and moisture exchangers, Critically ill patients

\footnotetext{
* Correspondence: mayra_menegueti@yahoo.com.br

${ }^{1}$ Escola de Enfermagem de Ribeirão Preto, Universidade de São Paulo, Ribeirão Preto, SP, Brazil

${ }^{2}$ Hospital das Clínicas da Faculdade de Medicina de Ribeirão Preto - USP, Divisão de Terapia Intensiva, Departamento de Cirurgia e Anatomia - 20 andar, Av. Bandeirantes, 3900 - Bairro Monte Alegre, Ribeirão Preto, SP, Brazil Full list of author information is available at the end of the article
} 


\section{Background}

Nosocomial pneumonia remains to be one of the main causes of infection in intensive care units (ICU) [1,2]. This condition is associated with the length of hospital stay [1,3], duration of mechanical ventilation, and use of broad-spectrum antibiotics. In the particular case of Brazil, nosocomial pneumonia is the primary cause of infection among critically ill patients admitted to the ICU, which is associated with increased hospital costs $[1,2,4-6]$ and mortality $[3,6]$. This type of pneumonia occurs more frequently in patients submitted to mechanical ventilation for over $48 \mathrm{~h}$, so it is commonly designated ventilator-associated pneumonia (VAP) [7]. VAP diagnosis relies on the emergence of a new pulmonary infiltrate or the presence of progressive pulmonary filtrate accompanied by fever, leukocytosis, and purulent secretion [7]. Mortality due to VAP varies between 24 and $50 \%$ and may reach rates as high as $76 \%$ in patients with comorbidities such as COPD, diabetes and other chronic lung diseases [8].

Mechanical ventilation suppresses the natural mechanisms that moisturize and heat inhaled air. When patients use an artificial airway, it is necessary to couple the ventilation system with a device that compensates for this suppression [9]. The lack of adequate moisturizing may thicken the secretions, which augments resistance to the passage of air, reduces the gas exchange effectiveness, and increases the risk of respiratory infections [10]. Air moisturizing and heating can be achieved actively (through the use of heated humidifiers, $\mathrm{HH}$ ) or passively (by means of heat and moisture exchangers, HME) [1].

Patients may acquire VAP by aspirating the condensation of water (ie, overhumidification) that originates in the ventilator circuit upon use of a conventional humidifier. The bacteria that colonize the patients themselves can proliferate in the condensate and then return to the airways and lungs when the patient aspirates this contaminated material [10-12]. Therefore, the use of HME might contribute to preventing pneumonia and lowering the VAP incidence.

Many research papers have compared HME and $\mathrm{HH}$ in terms of VAP occurrence [13-17]. However, data about how effectively HME prevents VAP remain inconclusive. Hence, this study aimed to evaluate how the use of HME impacts the probability of VAP occurrence in critically ill patients.

\section{Methods}

\section{Data sources and search strategies}

This is a systematic review of the literature with metaanalysis. The methodology involved six stages: selection of the hypothesis, selection of the studies, definition of the characteristics, analysis of the studies included in this revision, interpretation of the results, and synthesis of the results.
On the basis of the acronym "PICO" (Patient, Intervention, Comparison, Outcome), the question that guided this review was "Do critically ill patients under invasive mechanical ventilation present lower VAP incidence when they use HME as compared with HH?". Two of the authors of this review searched the databases PUBMED/Medline, The Cochrane Library, and Latin-American and Caribbean Literature in Health Sciences, LILACS independently; they used the following keywords: "heat and moisture exchanger", AND "heated humidifier", AND "ventilatorassociated pneumonia prevention". Table 1 presents the strategy these authors used to search for scientific evidence in the databases. This review included papers in the English language published from January 1990 to December 2012.

\section{Study selection}

This review only considered controlled randomized clinical assays that evaluated the use of HME as compared with $\mathrm{HH}$ to prevent VAP in critically ill patients. Exclusion criteria included: studies that did not associate the use of exchanger with VAP, experimental (non-clinical) studies, economic assessments and reviews, and articles that were not fully available. The following information was relevant for data collection: (1) paper identification (paper and journal title, main author, year of publication, and study locations); (2) assessment criteria used in the studies (exchanger type); (3) methodological characteristics [study type, study aims, results (impact of the exchanger on VAP prevention and possible complications), limitations, and conclusions]. The final sample consisted of 10 articles. Figure 1 illustrates the inclusion process.

\section{Data analysis and statistical methods}

The model to assess the quality of clinical assays proposed by the Oxford Centre for Evidence-based Medicine-Levels of Evidence (2009) helped to evaluate the quality of the evidence. Meta-analysis considered two outcomes, namely VAP occurrence and mortality rate among patients belonging to the HME (Intervention A) and the HH (Intervention $\mathrm{B}$ ) groups, which meant that the outcomes were dichotomous. Odds Ratio (OR) and its 95\% Confidence Interval $(95 \% \mathrm{CI})$ were used for the results of each study and for the synthesis. The Cochran's $Q$ and the $I$-square $\left(I^{2}\right)$ tests aided evaluation of heterogeneity. All the data were reported considering 95\% CI and two-tailed p values. The random effects model was employed in the case of significant heterogeneity among the studies $\left(I^{2}>50\right)$. The fixed effects model was applied for non-significant heterogeneity $\left(I^{2}<50\right)$. The meta-analysis was graphically represented by a Forest plot; the publication bias will be represented by a funnel plot. The software Comprehensive Meta Analysis ${ }^{\text {Tu }}$ version 2.2.064 (CMA Inc. USA) was employed to analyze and record data. 
Table 1 Search in electronic databases conducted on 01 st December 2012

\begin{tabular}{|c|c|c|}
\hline Electronic base & Search strategy & Studies \\
\hline Medline & $\begin{array}{l}\text { (("Heat and Moisture Exchanger" AND ("heated humidifier") AND ("ventilator associated pneumonia" OR "ventilator } \\
\text { associated pneumonia prevention")) }\end{array}$ & 1319 \\
\hline \multirow[t]{2}{*}{$\begin{array}{l}\text { The Cochrane } \\
\text { Library }\end{array}$} & $\begin{array}{l}\text { (("Heat and Moisture Exchanger" AND ("heated humidifier") AND ("ventilator associated pneumonia" OR "ventilator } \\
\text { associated pneumonia prevention")) }\end{array}$ & 50 \\
\hline & (Selection criteria: review studies and clinical assays) & \\
\hline LILACS & $\begin{array}{l}\text { (("Filtro Trocador de Calor e Umidade" E (Umidificador aquecido") ("Pneumonia associada à Ventilação Mecânica" OU } \\
\text { "Prevenção de Pneumonia associada à Ventilação Mecânica")). (("Heat and Moisture Exchanger" AND ("heated humidifier") } \\
\text { AND ("ventilator associated pneumonia" OR "ventilator associated pneumonia prevention")) }\end{array}$ & 93 \\
\hline
\end{tabular}

\section{Results}

This review included ten studies. Table 2 summarizes the main results and depicts the characteristics of each publication in detail, including the level of evidence provided by each study.

Table 3 compares the VAP incidence and mortality in the different clinical assays.

Meta-analysis provided a synthesis of the results considering the VAP outcome in the ten clinical assays selected for this review (Figure 2).
Comparison between the use of $\mathrm{HME}$ and $\mathrm{HH}$, in this meta-analysis did not reveal any differences in terms of VAP occurrence $(\mathrm{OR}=0.998$; 95\% CI: $0.778-1.281$ ). Together, the ten studies corresponded to a total sample of 1077 and 953 patients in the HME and HH groups, respectively; heterogeneity among the investigations was low $\left(\mathrm{I}^{2}<50 \%\right)$.

Information about the outcome mortality was available in only eight of the ten studies. Hence, the results synthesis can be seen in the referent meta-analysis (Figure 3).

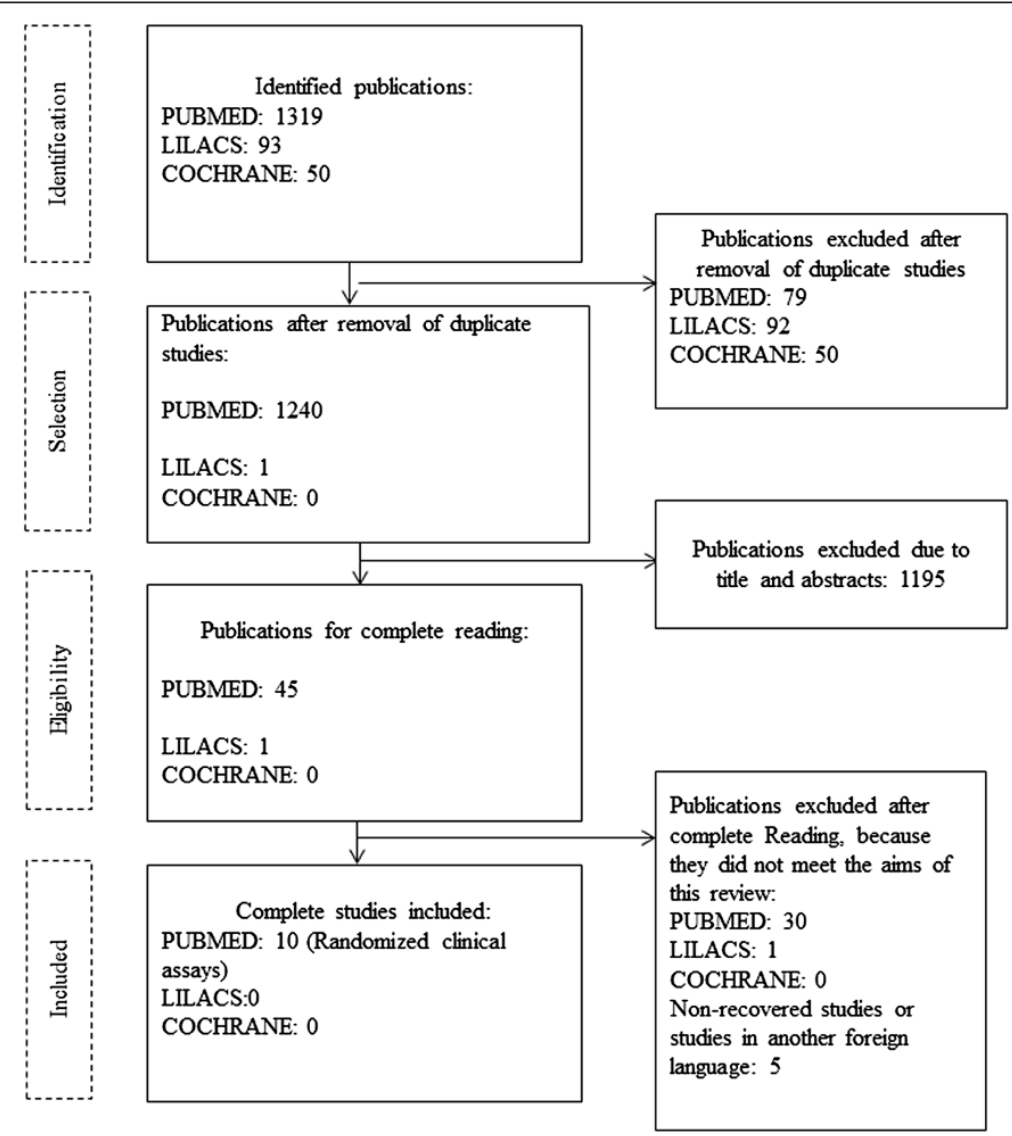

Figure 1 Flow chart for the selection of studies included in this review. 
Table 2 Characterization of the studies on the use of heat and moisture exchangers as compared with the conventional humidifiers

\begin{tabular}{|c|c|c|c|c|c|c|}
\hline Study/Country & Setting & Data analysis & Study limitations & Complications & Other benefits & Evidence level \\
\hline \multirow[t]{2}{*}{ Martin et al., 1990 [23] } & \multirow[t]{2}{*}{ ICU } & \multirow[t]{2}{*}{$\begin{array}{l}\text { Quantitative variables were } \\
\text { compared using the Student t } \\
\text { test. }\end{array}$} & \multirow[t]{2}{*}{$\begin{array}{l}\text { Pneumonia was diagnosed on } \\
\text { the basis of purulent secretion. It } \\
\text { did not involve VAP incidence } \\
\text { density. }\end{array}$} & $\begin{array}{l}\text { Hypothermia in } 22 \% \text { and } 12 \% \text { of } \\
\text { the patients belonging to the } \\
\text { HME and HH groups, respectively } \\
(p<0.01) \text {. Six and no cases of } \\
\text { tube occlusion were reported in } \\
\text { the HME and HH groups, } \\
\text { respectively }(p<0.01) \text {. }\end{array}$ & \multirow[t]{2}{*}{ Not reported. } & \multirow[t]{2}{*}{$1 \mathrm{C}$} \\
\hline & & & & $\begin{array}{l}\text { The study was interrupted after } \\
\text { the death of a patient belonging } \\
\text { to the HME group due to total } \\
\text { obstruction of the endotracheal } \\
\text { tube. }\end{array}$ & & \\
\hline \multirow[t]{2}{*}{ Roustan et al., 1992 [26] } & \multirow[t]{2}{*}{$\mathrm{ICU}$} & \multirow[b]{2}{*}{$\begin{array}{l}\text { Both groups were compared } \\
\text { using the Student t, Mann- } \\
\text { Whitney, Chi-square, and Fisher } \\
\text { exact tests for differences in } \\
\text { frequency. Regression was } \\
\text { conducted for the incidence of } \\
\text { nosocomial pneumonia, } \\
\text { atelectasis, and tube occlusion. }\end{array}$} & Sample size was not calculated. & \multirow{2}{*}{$\begin{array}{l}\text { Nine and no events of } \\
\text { endotracheal tube occlusion in } \\
\text { the HME and } \mathrm{HH} \text { groups, } \\
\text { respectively. Nine and ten } \\
\text { episodes of atelectasis in the HH } \\
\text { and HME groups, respectively. }\end{array}$} & \multirow[t]{2}{*}{ Not reported. } & \multirow[t]{2}{*}{$1 \mathrm{C}$} \\
\hline & & & $\begin{array}{l}\text { The randomization procedure } \\
\text { was not described. }\end{array}$ & & & \\
\hline Dreyfuss et al., 1995 [22] & $\mathrm{ICU}$ & $\begin{array}{l}\text { The Student } t \text { test was used for } \\
\text { the continuous variables. The } \\
\text { Chi-square test with Yates } \\
\text { correction was employed for the } \\
\text { categorical variables. The Mann- } \\
\text { Whitney test was used to } \\
\text { compare non-parametric } \\
\text { variables. }\end{array}$ & $\begin{array}{l}\text { The randomization procedure } \\
\text { was not described. Various } \\
\text { patients were excluded after } \\
\text { randomization. Sample size } \\
\text { calculation was not reported. }\end{array}$ & $\begin{array}{l}\text { Report of severe occlusion that } \\
\text { required cannula exchange due } \\
\text { to clotting (patients with } \\
\text { hematemesis) in the HME group. } \\
\text { Six patients required cannula } \\
\text { exchange due to obstruction by } \\
\text { secretion in the HME group. }\end{array}$ & $\begin{array}{l}\text { The use of HME reduces costs } \\
\text { and staff working time. }\end{array}$ & $1 C$ \\
\hline Boots et al., 1997 [21] & ICU & $\begin{array}{l}\text { The patients' characteristics were } \\
\text { compared by paired } t \text { test. The } \\
\text { VAP rate was evaluated using the } \\
\text { log rank test. }\end{array}$ & $\begin{array}{l}\text { The randomization procedure } \\
\text { was not described. }\end{array}$ & Not reported. & The use of HME reduces costs. & $1 \mathrm{C}$ \\
\hline Kirton et al., 1997 [24] & ICU & $\begin{array}{l}\text { Analysis of variance and non- } \\
\text { paired Student t test. }\end{array}$ & $\begin{array}{l}\text { Non-blinded study. ICU } \\
\text { specifically admitted trauma } \\
\text { patients. }\end{array}$ & $\begin{array}{l}\text { The HME and HH groups did not } \\
\text { differ in terms of endotracheal } \\
\text { tube obstruction. }\end{array}$ & The use of HME reduces costs. & $1 \mathrm{C}$ \\
\hline \multirow[t]{3}{*}{ Kollef et al., 1998 [25] } & \multirow[t]{3}{*}{ ICU } & $\begin{array}{l}\text { Student } t \text { and Wilcoxon tests } \\
\text { were used (according to normal } \\
\text { and non-normal distribution). }\end{array}$ & $\begin{array}{l}\text { The randomization procedure } \\
\text { was not described. No mention } \\
\text { of blinded study. }\end{array}$ & \multirow[t]{3}{*}{$\begin{array}{l}\text { Tube obstruction was not } \\
\text { detected in any of the groups. }\end{array}$} & \multirow[t]{3}{*}{$\begin{array}{l}\text { The use of HME reduces costs by } \\
50 \% \text {. }\end{array}$} & \multirow[t]{3}{*}{$1 \mathrm{C}$} \\
\hline & & $\begin{array}{l}\text { Chi-square and exact Fisher tests } \\
\text { were employed to compare } \\
\text { categorical variables. }\end{array}$ & $\begin{array}{l}\text { Time elapsed during filter } \\
\text { exchange was not controlled. }\end{array}$ & & & \\
\hline & & $\begin{array}{l}\text { Results were confirmed by } \\
\text { multiple logistic regressions. }\end{array}$ & $\begin{array}{l}\text { VAP diagnosis criteria did not } \\
\text { include bronchoalveolar lavage. }\end{array}$ & & & \\
\hline
\end{tabular}

The randomization procedure was not described. Various patients were excluded after randomization. Sample size correction was employed for the Whitney test was used to compare non-parametric

The patients' characteristics were

og rank test. 
Table 2 Characterization of the studies on the use of heat and moisture exchangers as compared with the conventional humidifiers (Continued)

\begin{tabular}{|c|c|c|c|c|c|c|}
\hline Memish et al., 2001 [20] & ICU & $\begin{array}{l}\text { The Student } t \text { test was } \\
\text { employed. }\end{array}$ & $\begin{array}{l}\text { The statistical power was not } \\
\text { calculated. }\end{array}$ & Not reported. & $\begin{array}{l}\text { Nursing staff spends less time } \\
\text { discarding the condensate that } \\
\text { builds up in the circuit. The use } \\
\text { of HME reduces costs. }\end{array}$ & $1 \mathrm{C}$ \\
\hline Lacherade et al., 2005 [14] & ICU & $\begin{array}{l}\text { The Student t test was employed } \\
\text { for continuous variables. The Chi- } \\
\text { square test was used for the } \\
\text { categorical variables. Multivariate } \\
\text { logistic regression was also } \\
\text { performed. }\end{array}$ & $\begin{array}{l}\text { Differences between the two } \\
\text { populations with respect to HIV } \\
\text { infection. Physicians and } \\
\text { researchers were not blinded. }\end{array}$ & $\begin{array}{l}\text { Tube occlusion rates were lower } \\
\text { in the HME group ( } 1 \text { case) as } \\
\text { compared with the HH group } \\
\text { ( } 5 \text { cases). }\end{array}$ & $\begin{array}{l}\text { On the basis of literature studies, } \\
\text { the paper mentions that the use } \\
\text { of HME reduces costs. }\end{array}$ & $1 C$ \\
\hline Boots et al., 2006 [15] & ICU & $\begin{array}{l}\text { Sample size was determined } \\
\text { using the difference between } \\
\text { two ratios. Univariate analysis } \\
\text { involved the use of Student t } \\
\text { and Kruskal-Wallis tests. The } \\
\text { difference in VAP rate among } \\
\text { groups was evaluated by Kaplan- } \\
\text { Meier and log rank tests. }\end{array}$ & $\begin{array}{l}\text { Pneumonia was diagnosed } \\
\text { according to CPIS (Clinical } \\
\text { Pulmonary Infection Score). }\end{array}$ & $\begin{array}{l}\text { HME may present higher } \\
\text { resistance to airflow than the } \\
\text { manufacturer's specifications } \\
\text { after use for } 24 \mathrm{~h} \text {. }\end{array}$ & The use of HME reduces costs. & $1 \mathrm{C}$ \\
\hline Lorente et al., 2006 [19] & ICU & $\begin{array}{l}\text { Quantitative variables were } \\
\text { compared using the Student t } \\
\text { test. Five risk models } \\
\text { proportional to Cox were } \\
\text { constructed for VAP analysis. }\end{array}$ & $\begin{array}{l}\text { Temperature and moisture were } \\
\text { not monitored. VAP diagnosis } \\
\text { was confirmed by tracheal } \\
\text { aspirate. After randomization, } \\
\text { patients under mechanical } \\
\text { ventilation for less than five days } \\
\text { were excluded. Sample } \\
\text { calculation was conducted, but it } \\
\text { did not reach a sufficient } \\
\text { number of patients. Wide } \\
\text { confidence interval. Incidence } \\
\text { density was not approached. } \\
\text { Immunosuppressed patients } \\
\text { were excluded. }\end{array}$ & Not reported. & $\begin{array}{l}\text { No benefits have been reported } \\
\text { for the use of HME. }\end{array}$ & $1 \mathrm{C}$ \\
\hline
\end{tabular}


Table 3 Description of the participants, VAP incidence, and mortality in the selected clinical assays

\begin{tabular}{|c|c|c|c|c|c|c|c|c|}
\hline \multirow[t]{2}{*}{ Paper } & \multicolumn{2}{|c|}{ Sample size } & \multicolumn{2}{|c|}{$\begin{array}{c}\text { VAP incidence } \\
\text { (\% or per } 1000 \text { mechanically ventilated patients/day) }\end{array}$} & \multirow[t]{2}{*}{$p$ value } & \multicolumn{2}{|c|}{ Mortality (\%) } & \multirow[t]{2}{*}{$p$ value } \\
\hline & HME group & HH group & HME group & HH group & & HME group & HH group & \\
\hline $\begin{array}{l}\text { Martin et al., } \\
1990[23]\end{array}$ & 31 patients under MV & 42 patients under MV & $7 \%$ & $19 \%$ & $>0.05$ & 22 & 26 & $>0.05$ \\
\hline $\begin{array}{l}\text { Roustan et al., } \\
1992 \text { [26] }\end{array}$ & 55 patients under MV & 61 patients under MV & $9.1 \%$ & $14.8 \%$ & $>0.05$ & 24.6 & 18.2 & $>0.05$ \\
\hline \multirow{2}{*}{$\begin{array}{l}\text { Dreyfuss et al., } \\
1995 \text { [22] }\end{array}$} & \multirow{2}{*}{$\begin{array}{l}61 \text { patients } \\
\text { under } \mathrm{MV}\end{array}$} & \multirow[t]{2}{*}{70 patients under MV } & $9.8 \%$ (6 cases) & $11.4 \%$ (8 cases) & \multirow[t]{2}{*}{$>0.05$} & \multirow[t]{2}{*}{28} & \multirow[t]{2}{*}{17} & \multirow[t]{2}{*}{$>0.05$} \\
\hline & & & $\begin{array}{l}\text { Confidence interval: } \\
3.7-20.2 \%\end{array}$ & $\begin{array}{l}\text { Confidence interval: } \\
5.1-21.3 \%\end{array}$ & & & & \\
\hline $\begin{array}{l}\text { Boots et al., } \\
1997[21]\end{array}$ & 75 patients under MV & 41 patients under MV & $19 \%$ & $17 \%$ & $>0.05$ & 17.3 & 9.7 & $>0.05$ \\
\hline \multirow{3}{*}{$\begin{array}{l}\text { Kirton et al., } \\
1997[24]\end{array}$} & \multirow{3}{*}{$\begin{array}{l}140 \text { patients } \\
\text { under MV }\end{array}$} & \multirow[t]{3}{*}{140 patients under MV } & \multirow{2}{*}{$\begin{array}{l}\text { Early: } 35 \text { VAP cases per } \\
\text { one thousand ventilated } \\
\text { patients per day }\end{array}$} & \multirow{2}{*}{$\begin{array}{l}\text { Early: } 31 \text { VAP cases per } \\
\text { one thousand ventilated } \\
\text { patients per day }\end{array}$} & Early: $p=>0.05$ & & & \\
\hline & & & & & \multirow[t]{2}{*}{ Late: $<0.05$} & & Rota net chour & \\
\hline & & & $\begin{array}{l}\text { Late: } 12 \text { VAP cases per } \\
\text { one thousand ventilated } \\
\text { patients per day }\end{array}$ & $\begin{array}{l}\text { Late: } 26 \text { VAP cases per } \\
\text { one thousand ventilated } \\
\text { patients per day }\end{array}$ & & & Dald not snown & \\
\hline \multirow{3}{*}{$\begin{array}{l}\text { Kollef et al., } \\
1998 \text { [25] }\end{array}$} & \multirow{3}{*}{$\begin{array}{l}163 \text { patients } \\
\text { under MV }\end{array}$} & \multirow[t]{3}{*}{147 patients under MV } & \multirow{3}{*}{$\begin{array}{l}20 \text { VAP cases per one } \\
\text { thousand ventilated } \\
\text { patients per day }\end{array}$} & \multirow{3}{*}{$\begin{array}{l}27.6 \text { VAP cases per } \\
\text { one thousand ventilated } \\
\text { patients per day }\end{array}$} & Relative Risk: 0.90 & \multirow[t]{3}{*}{24.5} & \multirow[t]{3}{*}{26.5} & \multirow[t]{3}{*}{$>0.05$} \\
\hline & & & & & Cl: 0.46-1.78 & & & \\
\hline & & & & & $p>0.05$ & & & \\
\hline $\begin{array}{l}\text { Memish et al., } \\
2001[20]\end{array}$ & $\begin{array}{l}123 \text { patients } \\
\text { under MV }\end{array}$ & 120 patients under MV & $\begin{array}{l}13.3 \text { VAP cases per one } \\
\text { thousand ventilated } \\
\text { patients per day. }\end{array}$ & $\begin{array}{l}15.7 \text { VAP cases per one } \\
\text { thousand ventilated } \\
\text { patients per day. }\end{array}$ & $p>0.05$ & 28.8 & 25 & $>0.05$ \\
\hline \multirow{3}{*}{$\begin{array}{l}\text { Lacherade et al., } \\
2005[14]\end{array}$} & \multirow{3}{*}{$\begin{array}{l}186 \text { patients } \\
\text { under MV }\end{array}$} & \multirow[t]{3}{*}{184 patients under MV } & \multirow{3}{*}{$\begin{array}{l}27.4 \text { VAP cases per one } \\
\text { thousand ventilated } \\
\text { patients per day }\end{array}$} & \multirow{3}{*}{$\begin{array}{l}25.3 \text { VAP cases per one } \\
\text { thousand ventilated } \\
\text { patients per day }\end{array}$} & 0.76 & \multirow[t]{3}{*}{32.4} & 34.2 & $>0.05$ \\
\hline & & & & & $\begin{array}{l}\text { Odds Ratio } \\
(0.58-1.57)\end{array}$ & & & \\
\hline & & & & & $p>0,05$ & & & \\
\hline Boots et al., & 190 patients & $2 \mathrm{HH}$ groups & $13 \%$ & - Group with heating upon & 0.61 & 15 & - Group with heating & $>0.05$ \\
\hline 2006 [15] & & $\begin{array}{l}\text { - Group with heating upon } \\
\text { inspiration: } 94\end{array}$ & & & & & & \\
\hline & & $\begin{array}{l}\text { - Group with heating upon } \\
\text { inspiration and expiration: } 97\end{array}$ & & $\begin{array}{l}\text { - Group with heating upon } \\
\text { inspiration and expiration: } 10 \%\end{array}$ & & & $\begin{array}{l}\text { - Group with heating } \\
\text { upon inspiration and } \\
\text { expiration: } 22\end{array}$ & \\
\hline $\begin{array}{l}\text { Lorente et al., } \\
2006[19]\end{array}$ & $\begin{array}{l}53 \text { patients } \\
\text { under MV }\end{array}$ & 51 patients under MV & 21 episodes (39\%) & 8 episodes (15\%) & $\begin{array}{l}\text { Hazard Ratio } 16.2 \\
(4.54-58.04)\end{array}$ & & Data not shown & \\
\hline & & & & & $p<0.05$ & & & \\
\hline
\end{tabular}

HME: Heat and moisture exchangers; HH: Heated Humidifiers; MV: Mechanical Ventilation; VAP: Ventilator-Associated Pneumonia. 


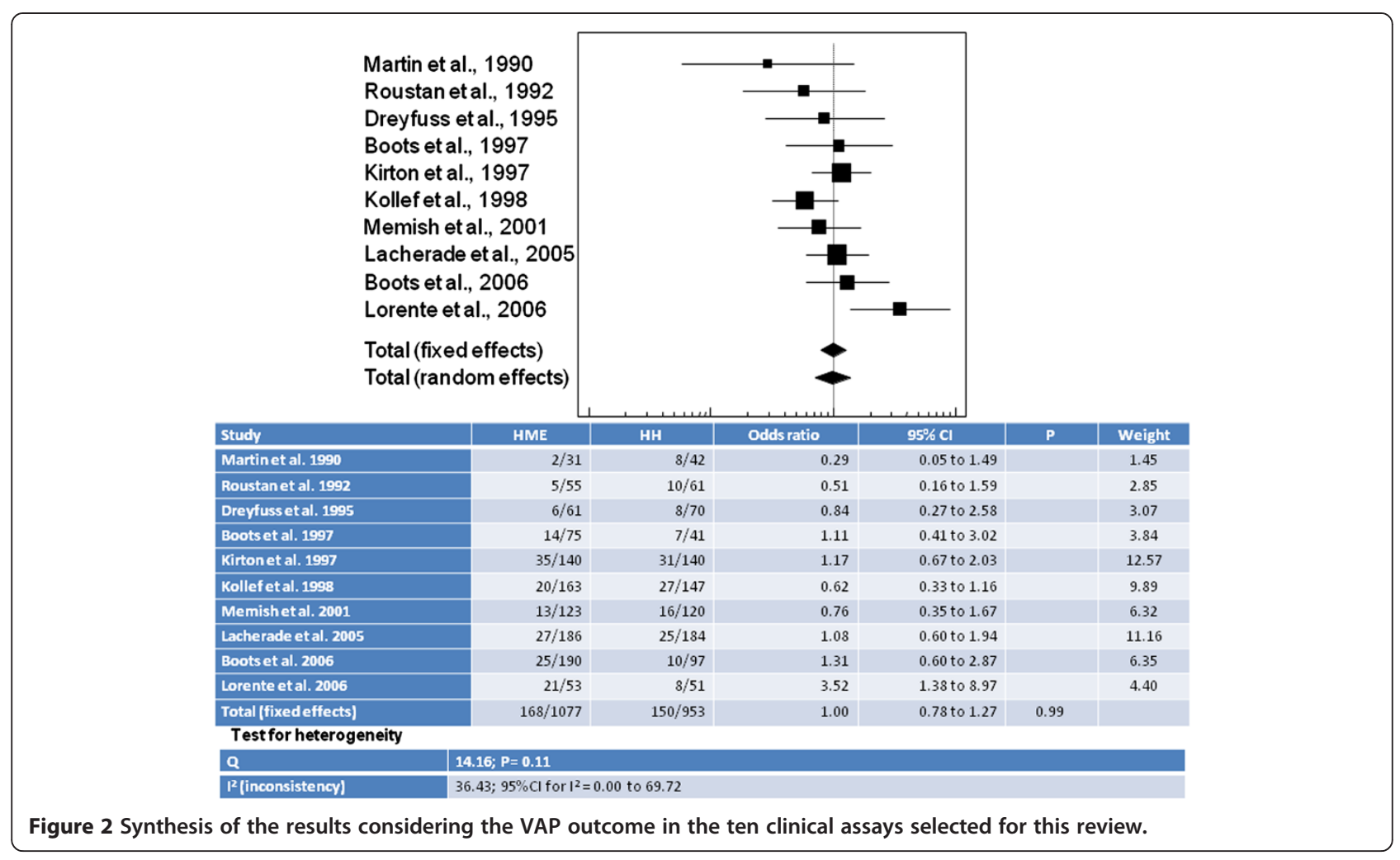

In this meta-analysis the use of HME and $\mathrm{HH}$ was not associated with different rates/risk of mortality $(\mathrm{OR}=1.09$; 95\% CI: 0.864-1.376). The total sample size was 884 and 762 patients, respectively. Heterogeneity among the studies was low $\left(\mathrm{I}^{2}=0.0 \%\right)$.

Considering the two outcomes investigated here, Figure 4 does not evidence any publication bias.

\section{Discussion}

Literature studies have presented conflicting results about how HME impacts VAP prevention. A meta-analysis including nine studies and 1368 patients revealed that HME reduced VAP rates especially in the case of subjects submitted to mechanical ventilation for over seven days $(R R=0.7$; IC 95\%: 0.50-0.94). However, non-randomized studies (not included in this meta-analysis) found significantly lower VAP rates in the groups that used $\mathrm{HH}$ as compared with HME [18]. Other two randomized studies reported nonsignificantly different VAP rates for HH and HME $[14,15]$. A randomized study of 120 patients demonstrated smaller VAP incidence during the use of $\mathrm{HH}$ in patients under mechanical ventilation for periods longer than five days (15.69 vs $39.62 \%, \mathrm{P}=0.006$ ) [19]. A meta-analysis published by Siempos et al. (2007) [16] included 13 randomized clinical assays and 2,580 patients; it did not detect any differences between HME and $\mathrm{HH}$ with respect to VAP incidence, mortality in the ICU, length of stay in the ICU, period of mechanical ventilation, or airway obstruction.
Most studies have found similar VAP rates for HME and $\mathrm{HH}$ [14-18,20-26]. In most of these studies, the HME and $\mathrm{HH}$ groups did not differ in terms of VAP incidence density, period of mechanical ventilation, length of stay in the ICU, or global mortality rate.

Kirton et al. (1997) [24] evaluated 280 trauma patients and demonstrated lower VAP incidence during the use of HME. On the other hand, Auxiliadora-Martins et al. (2012) [17] investigated severely ill patients (mean APACHE II score $>25$ ) with associated comorbidities, to find that the $\mathrm{HH}$ and HME group did not have different VAP incidence. The heterogeneous study populations, the distinct brands of HME employed in the aforementioned studies, the frequency with which the nursing staff changed the moisturizer, and the criteria used to diagnose VAP may have contributed to these contrasting results [19]. Nevertheless, HME did offer advantages over HH: it did not require that the staff opened the device circuit to remove the condensate accumulated in the ventilator extensions, which reduced the occupational risk and optimized the work of the nursing team. In addition, it may have some disadvantages using $\mathrm{HH}$; such as high maintenance costs and mechanical malfunction of the humidification and mechanical ventilator apparatus, and overheating of the inspired gases. These problems could be avoided by using HME [10-12,17].

Even though many studies have shown that the use of HME incurs lower costs $[14,15,21,22,24,25]$, this device 


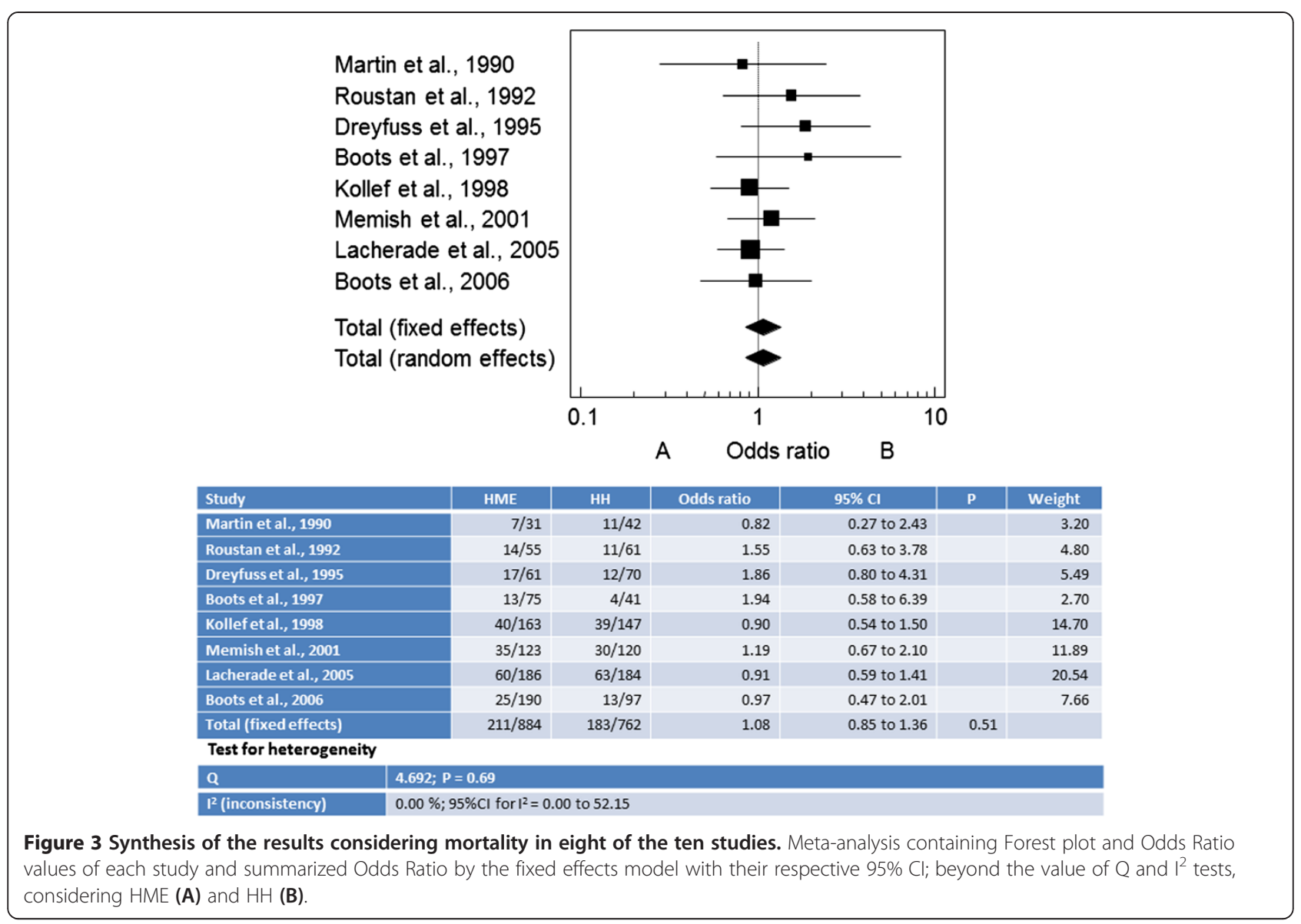

is not risk-free. Partial or total tube occlusion is the most probable adverse effect, and its frequency is significantly different in patients submitted to $\mathrm{HME}$ and $\mathrm{HH}$ $[14,22,23,26]$. Lower moisture production may account for this difference, especially during application of larger minute volumes. This is a common event in all the commercially available devices, albeit to different extent [27-29]. Martin et al. (1990) [23] have also described more frequent cases of hypothermia in patients using HME. In contrast, Kirton et al. (1997) [24] and Kollef et al. (1998) [25] did not observe any differences between the $\mathrm{HH}$ and HME groups in terms of tube occlusion. The use of HME involves other concerns: increased dead volume due to hypercapnia and larger airway resistance, which depend mainly on the filter internal volume and liquid accumulation, respectively [29-31].

In most studies the change of HME was every 24 or 48 hours according manufacturer's recommendation. Other studies have demonstrated that prolonged use of HME, from 24-48 h up to four or seven days, does not
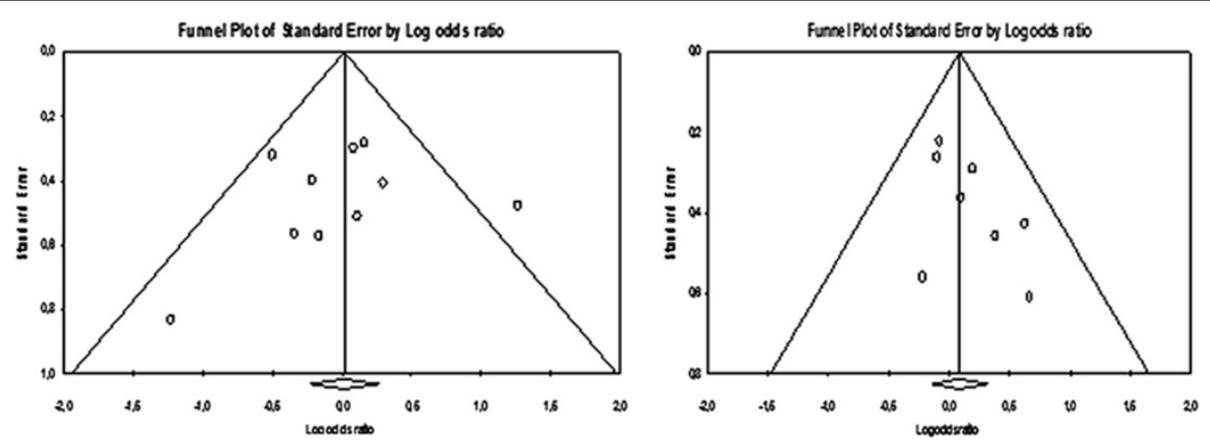

Figure 4 Considering the two outcomes investigated here, there was no evidence any publication bias. Funnel plot showing that there is no evidence of publication bias on VAP (A) and mortality (B) outcomes. 
incur increased risk of VAP [31-35]. Davis et al. did not detect reduced efficiency, increased resistance, or altered bacterial colonization when the use of HME was discontinued after three days. The VAP incidence rate did not change, either, so the authors concluded that the use of HME for over $24 \mathrm{~h}$, up to $72 \mathrm{~h}$, is safe and economically advantageous.

Together, the analyzed studies suggest that it is possible to use either $\mathrm{HH}$ or HME without significantly impacting the VAP incidence. Considering hospital costs and in the absence of contraindications, HME should be employed as an alternative humidifier in patients submitted to mechanical ventilation. The results of the present review agree with the pathophysiology proposed for VAP in the sense that bacteria inoculation into the lungs generally occurs via extraluminal source, whereas only occasionally does the intraluminal pathway happen.

Considering a $30 \%$ reduction in the occurrence of VAP among patients who used respectively, $\mathrm{HH}(16 \%)$ and HME (11\%), with a significance level of $5 \%$ and a statistical power of $80 \%$, the minimum sample per group would be 731 subjects. In the present meta-analysis, it was evaluated studies with 953 subjects in the HH group and 1077 in the HME group, thus this review presents a sufficient sample size to detect this difference. However there are some potential limitations should be considered. Firstly, the sample size was sufficient to detect a $30 \%$ reduction in VAP rates; the power of the study was not sufficient to identify more modest reductions, although smaller reductions could still be important from a clinical perspective. Secondly, some studies were not calculated sample size and were not described the randomization procedure. Thirdly, in two studies patients were excluded after randomization and other two studies were non blinded. Finally, the definitions of VAP varied in some included studies. Thus other double-blind studies, randomized controlled should be performed to definitely exclude an associate between heat and moisture exchangers and VAP.

Hence, the studies included in this meta-analysis did not attest that the use of HME in the ICU setting reduced the VAP incidence or affected mortality rates. On the basis of these two outcomes (VAP incidence and mortality), the meta-analysis of the selected studies was reliable, given that the samples had low heterogeneity.

\section{Conclusion}

Current meta-analysis was not sufficient to definitely exclude an associate between heat and moisture exchangers and VAP. Despite the methodological limitations found in selected clinical trials, the current meta-analysis suggests, with some degree of uncertainty, that HME does not decrease VAP incidence or mortality in critically ill patients and therefore, further clinical trials with greater methodological rigor and adequate sample size should be performed comparing $\mathrm{HH}$ to HME in the incidence of VAP and other important outcomes such as mortality. Is important to highlight that, institutions routinely using HME should be aware of obstruction events and cases of hypercapnia and hypothermia, because some studies have described their occurrence.

\section{Consent}

Written informed consent was obtained from the patient for the publication of this report.

\section{Competing interests}

The authors declare that they have no competing interests.

\section{Authors' contributions}

MGM, contributed with data analysis and interpretation. AAN, contributed with statistical analysis. MA-M and MGM, contributed with drafting the article. MGM, MAM and AAN contributed with revising it critically for important intellectual content. All authors read and approved the final manuscript.

\section{Acknowledgments}

We are thankful to Fundação de Amparo ao Ensino, Pesquisa e Assistência (FAEPA) do Hospital das Clínicas and Faculdade de Medicina de Ribeirão Preto-USP.

\section{Author details}

${ }^{1}$ Escola de Enfermagem de Ribeirão Preto, Universidade de São Paulo, Ribeirão Preto, SP, Brazil. ${ }^{2}$ Hospital das Clínicas da Faculdade de Medicina de Ribeirão Preto - USP, Divisão de Terapia Intensiva, Departamento de Cirurgia e Anatomia - 20 andar, Av. Bandeirantes, 3900 - Bairro Monte Alegre, Ribeirão Preto, SP, Brazil. ºpartamento de Medicina Social, Av. Bandeirantes, 3900 Bairro Monte Alegre, Ribeirão Preto, SP, Brazil.

Received: 9 June 2014 Accepted: 5 December 2014

Published: 13 December 2014

\section{References}

1. Vincent $J$ L, Bihari DJ, Suter PM, Bruining HA, White J, Nicolas-Chanoin MH, Wolff M, Spencer RC, Hemmer M: The prevalence of nosocomial infection in intensive care units in Europe. Results of the European prevalence of infection in intensive care (EPIC) study. EPIC international advisory committee. JAMA 1995, 274:639-644.

2. Rello J, Ollendorf DA, Oster G, Vera-Llonch M, Bellm L, Redman R, Kollef MH: Epidemiology and outcomes of ventilator associated pneumonia in a large US database. Chest 2002, 122:2115-2121.

3. Bercault N, Boulain T: Mortality rate attributable to ventilator associated nosocomial pneumonia in an adult intensive care unit: a prospective case-control study. Crit Care Med 2001, 29:2303-2309.

4. Chen YY, Wang FD, Liu CY, Chou P: Incidence rate and variable cost of nosocomial infections in different types of intensive care units. Infect Control Hosp Epidemiol 2009, 30:39-46.

5. Warren DK, Shukla SJ, Olsen MA, Kollef MH, Hollenbeak CS, Cox MJ, Cohen MM, Fraser VJ: Outcome and attributable cost of ventilator-associated pneumonia among intensive care unit patients in a suburban medical center. Crit Care Med 2003, 31:1312-1317.

6. Safdar N, Dezfulian C, Collard HR, Saint S: Clinical and economic consequences of ventilator-associated pneumonia: a systematic review. Crit Care Med 2005, 33:2184-2193.

7. Horan TC, Andrus M, Dudeck MA: CDC/NHSN surveillance definition of health care-associated infection and criteria for specific types of infections in the acute care setting. Am J Infect Control 2008, 36:309-332.

8. Meduri GU: Diagnosis and differential diagnosis of ventilator associated pneumonia. Clin Chest Med 1995, 16:61-93.

9. Branson RD, Chatburn RL: Humidification of inspired gases during mechanical ventilation. Respir Care 1993, 38:461-468.

10. Hess DR, Kacmarek RM: Essentials of Mechanical Ventilation. New York: McGraw-Hill; 1996:33-40. 
11. Craven DE, Goularte TA, Make RJ: Contaminated condensate in mechanical ventilator circuits: a risk factor for nosocomial pneumonia? Am Rev Respir Dis 1984, 129:625-628.

12. Martin C, Thomachot L, Quinio R, Viviand X, Albanese J: Comparing two heat and moisture exchangers with one vaporizing humidifier in patients with minute ventilation greater than $10 \mathrm{~L} / \mathrm{min}$. Chest 1995, 107:1411-1415.

13. Kola A, Eckmanns T, Gastmeier P: Efficacy of heat and moisture exchangers in preventing ventilator-associated pneumonia: meta-analysis of randomized controlled trials. Intensive Care Med 2005, 31:5-11.

14. Lacherade JC, Auburtin M, Cerf C, Van de Louw A, Soufir L, Rebufat Y, Rezaiguia S, Ricard JD, Lellouche F, Brun-Buisson C, Brochard L: Impact of humidification systems on ventilator-associated pneumonia: a randomized multicenter trial. Am J Respir Crit Care Med 2005, 172:1276-1282.

15. Boots RJ, George N, Faoagali JL, Druery J, Dean K, Heller RF: Double-heaterwire circuits and heat-and-moisture exchangers and the risk of ventilator-associated pneumonia. Crit Care Med 2006, 34:687-693.

16. Siempos II, Vardakas KZ, Kopterides P, Falagas ME: Impact of passive humidification on clinical outcomes of mechanically ventilated patients: a meta-analysis of randomized controlled trials. Crit Care Med 2007, 35:2843-2851.

17. Auxiliadora-Martins M, Menegueti MG, Nicolini EA, Alkmim-Teixeira GC, BellissimoRodrigues F, Martins-Filho OA, Basile-Filho A: Effect of heat and moisture exchangers on the prevention of ventilator-associated pneumonia in critically ill patients. Braz J Med Biol Res 2012, 45(12):1295-1300.

18. Bench S: Humidification in the long-term ventilated patient; a systematic review. Intensive Crit Care Nurs 2003, 19(2):75-84.

19. Lorente L, Lecuona M, Jimenez A, Mora ML, Sierra A: Ventilator-associated pneumonia using a heated humidifier or a heat and moisture exchanger: a randomized controlled trial [ISRCTN88724583]. Crit Care 2006, 10:R116

20. Memish ZA, Oni GA, Djazmati W, Cunningham G, Mah MW: A randomized clinical trial to compare the effects of a heat and moisture exchanger with a heated humidifying system on the occurrence rate of ventilatorassociated pneumonia. Am J Infect Control 2001, 29:301-305.

21. Boots RJ, Howe S, George N, Harris FM, Faoagali J: Clinical utility of hygroscopic heat and moisture exchangers in intensive care patients. Crit Care Med 1997, 25:1707-1712

22. Dreyfuss D, Djedaini K, Gros I, Mier L, Le Bourdelles G, Cohen Y, Estagnasié $P$, Coste $F$, Boussougant $Y$ : Mechanical ventilation with heated humidifiers or heat and moisture exchangers: effects on patient colonization and incidence of nosocomial pneumonia. Am J Respir Crit Care Med 1995, 151:986-992.

23. Martin C, Perrin G, Gevaudan MJ, Saux P, Gouin F: Heat and moisture exchangers and vaporizing humidifiers in the intensive care unit. Chest 1990, 97:144-149.

24. Kirton OC, DeHaven B, Morgan J, Morejon O, Civetta J: A prospective, randomized comparison of an in-line heat moisture exchange filter and heated wire humidifiers: rates of ventilator-associated early-onset (community-acquired) or late-onset (hospital-acquired) pneumonia and incidence of endotracheal tube occlusion. Chest 1997, 112:1055-1059.

25. Kollef MH, Shapiro SD, Boyd V, Silver P, Von Harz B, Trovillion E, Prentice D: $A$ randomized clinical trial comparing an extended-use hygroscopic condenser humidifier with heated-water humidification in mechanically ventilated patients. Chest 1998, 113:759-767.

26. Roustan JP, Kienlen J, Aubas P, Aubas S, du Cailar J: Comparison of hydrophobic heat and moisture exchangers with heated humidifier during prolonged mechanical ventilation. Intensive Care Med 1992, 18:97-100.

27. Cohen IL, Weinberg PF, Alan I, Rowinsky GS: Endotracheal tube occlusion associated with the use of heat and moisture exchangers in the intensive care unit. Crit Care Med 1988, 16:277-279.

28. Doyle A, Joshi M, Frank P, Craven T, Moondi P, Young P: A change in humidification system can eliminate endotracheal tube occlusion. $J$ Crit Care 2011, 26(6):637.

29. Hurni JM, Feihl F, Lazor R, Leuenberger P, Perret C: Safety of combined heat and moisture exchanger filters in long-term mechanical ventilation. Chest 1997, 111:686-691.

30. Briassoulis G, Paraschou D, Hatzis T: Hypercapnia due to a heat and moisture exchanger. Intensive Care Med 2000, 26:147.
31. Wilkes AR: Heat and moisture exchangers and breathing system filters: their use in anaesthesia and intensive care. Part 1 - history, principles and efficiency. Anaesthesia 2011, 66:31-39.

32. Wilkes AR: Heat and moisture exchangers and breathing system filters: their use in anaesthesia and intensive care. Part 2 - practical use, including problems, and their use with paediatric patients. Anaesthesia 2011, 66:40-51.

33. Markowicz $P$, Ricard JD, Dreyfuss $D$, Mier $L$, Brun $P$, Coste $F$, Boussougant $Y$, Djedaïni K: Safety, efficacy, and cost-effectiveness of mechanical ventilation with humidifying filters changed every 48 hours: a prospective, randomized study. Crit Care Med 2000, 28:665-671.

34. Thomachot L, Boisson C, Arnaud S, Michelet P, Cambon S, Martin C: Changing heat and moisture exchangers after 96 hours rather than after 24 hours: a clinical and microbiological evaluation. Crit Care Med 2000 28:714-720.

35. Thomachot L, Leone M, Razzouk K, Antonini F, Vialet R, Martin C: Randomized clinical trial of extended use of a hydrophobic condenser humidifier: 1 vs. 7 days. Crit Care Med 2002, 30:232-237.

doi:10.1186/1471-2253-14-115

Cite this article as: Menegueti et al.: Effectiveness of heat and moisture exchangers in preventing ventilator-associated pneumonia in critically ill patients: a meta-analysis. BMC Anesthesiology 2014 14:115.

\section{Submit your next manuscript to BioMed Central and take full advantage of:}

- Convenient online submission

- Thorough peer review

- No space constraints or color figure charges

- Immediate publication on acceptance

- Inclusion in PubMed, CAS, Scopus and Google Scholar

- Research which is freely available for redistribution 